25 "Legislative measures"

26 "Blight, wart disease, leafroll"

27 "Fungi and the great war (1914-1918)

28 "Dusting and seed-disinfection"

29 "New sprays for old"

30 "Degeneration and virus diseases"

31 "Tawards immunity".

In het 26ste, 29ste en laatste hoofdstuk komt Phytophthora infestans weer naar voren. Wij lezen daarin o.a. ook over VAN Everdingen's analyse van het aan epidemiën voorafgaande weer, over het onderzoek van HELENA DE BRUYN, die kon aantonen, dat het sexueele proces, waarmee de oösporen-vorming wordt ingeleid, buiten de plant plaats heeft, en over de pogingen, die in verschillende landen worden verricht om tegen Phytophthora resistente aardappelrassen te kweeken door inkruising van in Zuid-Amerika opgespoorde niet of weinig vatbare Solanumsoorten.

Maar hoe de held van dit verhaal het aanlegt om uit zijn winterrust te ontwaken en zich opnieuw op zijn prooi te werpen, blijft nog een raadsel. Wanneer zal het vervolg op zijn levensgeschiedenis verschijnen?

Dit boek is geen leerboek in den gewonen zin, daarvoor worden er te weinig plantenziekten in behandeld. Het is een voortreffelijk stuk cultuurgeschiedenis, dat van even groote waarde is voor economen als voor de beoefenaars der natuurwetënschappen in ' $t$ algemeen en van phytopathologen in ' $t$ bijzonder.

H. M. Quanjer

\title{
NIEUW TIJDSCHRIFT
}

\section{PARASITICA}

Met veel genoegen kondigen wij hier de eerste aflevering aan van het nieuwo Belgische tijdschrift Parasitica, uitgegeven door de in Mei 1945 opgerichte Vereeniging voor de Studiën en Onderzoekingen van toegepaste Zoölogie en Phytopathologie (Association pour les Etudes et les Recherches de Zoologie appliquée et de Phytopathologie). Deze Vereeniging omvat twee afdeelingen, waarvan de eene betrekking heeft op medisch - on veterinair gebied, de andere landbouwkundig georiënteerd is en phytopathologie, toegepaste entomologie on phytopharmacie omvat. Parasitica, dat onder redactie staat van Prof $R$. van der Walle en Ir G. Roland, zal elke drie maanden verschijnen on zal gewijd zijn aan -onderwerpen, die betrekking hebben op beide gebieden. De artikelen kunnen in de beide landstalen geschreven zijn, doch de eorste aflevering bevat uitsluitend artikelen die in het Fransch zijn gesteld. Van der Walle beschrijft in een Note au sujot de quelques affections nouvellement constatées en Belgiquo o.a. een ziekto van Thuja, die de naalden aantast en die jonge planten tot afsterven brengt. De ziekte wordt door de schimmel Keythia Thujae veroorzaakt. Roland publiceert een uitvoerig artikel over een ziekte in de eiken. Een korte samenvatting vindt men in deze aflevering van het Tijdschrift over Plantenziekten.

Tenslotte publiceert Tilemans een artikel getiteld: Sur la Phytopharmacie. Hieronder wordt verstaan de wetenschap, die het gebruik van chemischo middelen in den strijd tegen parasieten (diorlijke en plantaardige), die plantep aantasten, bestudeert.

A. J. P. OORT 